\title{
Strengthening of masonry walls with CFRP composite: experiments and numerical modeling
}

\author{
HouRIA HERNOUNE - Department of Civil Engineering, University Yahia Fares, Algeria \\ BenchaA BENABED - Civil engineering laboratory, University of Amar Telidji, Algeria \\ MADYAN ALSHUGAA - Department of Civil Engineering, University King Fahd University of Petroleum \\ and Minerals, Saudi Arabia
}

RAJAB ABOUSNINA - Centre for Future Materials, School of Civil Engineering and Surveying, University of Southern Queensland, Australia

Abdelhamid GUETTALA - Department of Civil Engineering, University Mohamed Khider, Algeria

Érkezett: 2019. 12. 26. - Received: 26. 12. 2019. - https://doi.org/10.14382/epitoanyag-jsbcm.2020.1

\section{Abstract}

The paper presents the experimental and numerical study of brick masonry walls reinforced with carbon fiber-reinforced polymer (CFRP) composite subjected to a shear load. In this analysis the Concrete Damaged Plasticity (CDP) constitutive laws are utilzed to simulate the non-linearities in the behavior of brick and mortar. These models are used for the analysis of diagonal compression tests on masonry panels. The experimental results are used to validate the modelling approach presented here. The results showed that the application of the CFRP composite on unreinforced masonry (URM) has a great influence on strength, post-peak behavior, as well as changing failure modes and ductility. On the other hand, the adopted detailed micro-modelling approach (DMM) gives a good interface for predict the shear response on masonry walls.

Keywords: masonry walls, CFRP composites, shear loads, detailed micro-modelling approach, diagonal compression tests

Kulcsszavak: téglafalazatok, CFRP kompozitok, nyírás, részletes mikro-modellezési eljárás, átlós nyomószilárdság teszt
\end{abstract}

\section{Introduction}

Around the world, there are many old unreinforced masonry (URM) structures such as historical cultural monuments and bridges, etc. which are deteriorated or damaged during earthquake events $[1,2]$. In order to extend the life of such structures, strengthening or repairing by implementing new techniques have been developed. Many of these strengthening techniques including the use of fiber reinforced polymer (FRP) composites were used to reinforce masonry structures. These composites are manufactured in different features depending on the fiber material type like carbon fiber (CFRP), glass (GFRP), and aramid (AFRP). FRP strips offer the possibility of application by gluing on the outside surface EB (externally bonded) or inserting inside the groove of element by the near-surface mounted (NSM)technique. The use of FRP composites embedded into polymetric matrix such as (polyester, epoxy, mortar mix) can be the perfect solution for retrofit the structure walls in seismic area. The application of FRP composite to strengthen and rehabilitate masonry has been studied by several authors. Experimental studies evaluate the effect of different variables for example, the effect of retrofitting configuration of FRP composite, type of FRP composites and the type of masonry components, through small-scale testing such as triplets test, Wallette and by full scale testing. Mahmood and Ingham [3] conducted a series of experimental test on URM walls, they illustrated the effectiveness of FRP retrofitting system in improving the shear strength of unreinforced masonry with a factor of 3.25. Valluzzi et al [4] tested a series of unreinforced brick masonry panels strengthened by different materials (GFRP, CFRP and PVAFRP) of different configuration. All tested specimens were subjected to a diagonal compression test, the results showed that the application of FRP at one side of the wall only produces a significant out-of-plane deformation, corners and the failure mode of the out-of-plane displacement exaggerated by the little restraint at the top and bottom of the wall. Several researchers such as Haroun et al [5], Tumialam et al [6], Hamid et al [7] and Li et al [8] have shown that FRP composites can improve the shear capacities of URM walls significantly. All these experimental studies have shown that the use of FRP strengthening technique can ensure adequate increase of seismic capacity, stiffness and ductility of masonry wall in the in plane lateral loading $[9,10]$ or out-of-plane $[11]$.

To understand the structural behavior of the masonry wall during earthquakes, it is significant to model this using advanced technique. In the literature two major approaches have been developed for masonry modeling namely heterogeneous and homogeneous modeling. In the first approach the brick units and joint mortar are considered separately (heterogeneous modeling). While, in the second approach (homogeneous modeling) the brick units, joint mortar and interfaces between them are assumed to be either an isotropic or anisotropic composite material. According to the classification of Lourenco (1995) [12] there are two main modelling approaches: macro-modelling and micro-modelling (see Fig.1). The micro-modeling can be divided into two techniques as detailed micro-modeling and simplified micro modeling [13]. 


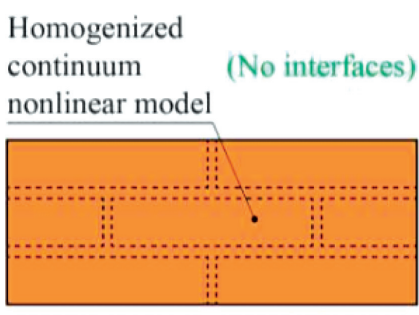

Macro-model
Mortar continuum

nonlinear model

Brick continuum Brick-mortar nonlinear model nonlinear interface

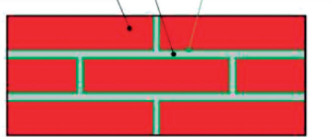

Detailed micro-model
Fig. 1 Modelling strategies for masonry structure

1. ábra Falazott szerkezetek modellezési stratégiái

In the detailed micro-modeling (see Fig. $1 b$ ) each component (units and mortar) is modeled separately with unit-mortar interface. The concept of micro modeling is adopted for analysis in detail of small masonry structural elements such as masonry shear triplets or small panel wall. In this approach the masonry units and mortar are modelled with real thickness, while zero thickness is assigned to unit-mortar interfaces. The units and mortar are modelled as continuum elements and unit-mortar interfaces are modelled as discontinuous elements.

The literature has been clearly focused on the importance of including all mechanisms of rupture of the masonry in the modeling to understand its behavior, in terms of ductility and ultimate load as well as the damage which is usually concentrated at the mortar interface $[14,15]$. In microscopic models, only a tensile breaking of the bricks is sometimes considered, most studies relying only on a linear elastic behavior of the bricks. Or in other words, the authors adopted this model assent to the need to introduce the post-peak softening behaviors of the mortar. The progressive cracking of the elements must be reproduced by the softening in tension. In shear, the degradation of the cohesion and that in compression leads to the crushing of the masonry. The softening behavior laws, which are thus essential in modeling, however, rely on the definition of many parameters whose values are difficult to be predicted. This modeling is therefore only feasible if it is coupled with a several experimental test for best description of the material and their interactions.

In the present study, the influence of the type of joint mortar and location of the CFRP composites in the strengthened panels subjected to shear loads is evaluated by diagonal compression test. For the numerical analysis, a numerical model based on the DMM approach was developed using FE software ABAQUS and validate with the experimental data. The result of these numerical examples is compared with the experimental result.

\section{Experimental program}

The test consists of testing four unreinforced walls (control panels noted MT) and six walls reinforced with CFRP composites in order to evaluate the reinforcement efficiency and the mode of rupture in case of each reinforcement.The reinforced panels were strengthened by Sika Warp carbon fiber CFRP composites of $50 \mathrm{~mm}$ width. The FRP reinforcement was glued, using two-part epoxy adhesive. Three configurations of the retrofit system were investigated.

\subsection{Materials}

\subsubsection{Brick units}

The perforated bricks were tested in compression and in bending. Five test series has been studied to obtain the average values of compressive strength and the elastic modulus. The tests were carried out using a hydraulic press according to the EN 771-1 [16].

\subsubsection{Cement-Lime mortar}

The cement-lime mortars are commonly adopted, because these mortars have the good properties of cement as well as lime mortars, that is, medium strength along with good water retentively, good workability and to some extent freedom from cracks. Therefore, this type of mortar has been adopted.

Two mixes consisting of cement: lime: sand proportions (1:1:3 and 1:1:5) were prepared using an electrical mixer by weight batching. Water was added and the mixture was remixed to achieve a workable consistency. In order to measure the mechanical properties of these mortars, the prepared mixtures were cast into standard molds and then maintained in the standard curing. The mechanical properties of mortars were determined at the age of 3, 7, 14 and 28 days after de-molding. Flexural and compressive strength tests were measured according to EN 1015-11 [17]. By using the universal testing machine, the flexural strength has been tested on specimens in the shape of a prism $40 \times 40 \times 160 \mathrm{~mm}^{3}$ . Afterward, the two half-prisms obtained after breaking into two parts from the specimen during the flexural test were subjected to the uniaxial compressive test (results are shown in Table 1). Six specimens of each mix are tested to have the average value of the response. The average values of the brick compressive strength, the mortars compressive strength and secant modulus of elasticity are reported in Table 1 .

\begin{tabular}{lccc}
\hline Material & $\begin{array}{c}\text { Compressive } \\
\text { strength (MPa) }\end{array}$ & $\begin{array}{c}\text { Flexural } \\
\text { strength (MPa) }\end{array}$ & $\begin{array}{c}\text { Young's modulus } \\
\text { (MPa) }\end{array}$ \\
$\begin{array}{l}\text { Mortar A } \\
(\mathbf{1 : 1 : 3 )}\end{array}$ & 7.187 & 3.341 & 3639.24 \\
\hline $\begin{array}{l}\text { Mortar B } \\
(\mathbf{1 : 1 : 5 )}\end{array}$ & 3.643 & 1.453 & 1880.87 \\
\hline Brick & 20.53 & - & $1 . \mathrm{E}+04$
\end{tabular}

Table 1 Compressive strength, flexural strength and young modulus of mortar and brick 1. táblázat A habarcs és tégla nyomószilárdsága, hajlitószilárdsága és rugalmassági modulusa

\subsubsection{Composite materials (SikaWrap carbon fiber)}

In this study, a unidirectional carbon fibre (Sika Wrap carbon fiber fabric) is employed. The technical characteristics are summarized in the following Table 2.

\begin{tabular}{cc} 
Property & Value \\
CFRP width & $300 / 600 \mathrm{~mm}$ \\
\hline CFRP length / roll & $\geq 50 \mathrm{~m}$ \\
\hline Weight & $235 \mathrm{~g} / \mathrm{m}^{2} \pm 10 \mathrm{~g} / \mathrm{m}^{2}$ \\
\hline Thickness & $0.129 \mathrm{~mm}$ \\
\hline Density (Fiber) & $1.82 \mathrm{~g} / \mathrm{cm}^{3}$ \\
\hline $\mathrm{E}_{\text {CFRP }}$ & $230 \mathrm{kN} / \mathrm{mm}^{2}$ \\
\hline Ft ${ }_{\text {CFRP }}$ & $4000 \mathrm{~N} / \mathrm{mm}^{2}$ \\
\hline Rupture strain & $1.70 \%$
\end{tabular}

Table 2 Mechanical properties of the CFRP reinforcing system (nominal values reported by the manufacturer

2. táblázat A CFRP mechanikai tulajdonságai (gyártó által közölt névleges értékek) 


\subsection{Methods}

The test specimens were made according to the instructions given in RILEM technical recommendation [18]. A series of ten masonry wallettes were constructed from perforated brick with dimensions $220 \times 105 \times 55 \mathrm{~mm}^{3}$ and mortar joint with $10 \mathrm{~mm}$ of thickness. Two types of mortar (type A, type B) were used in the construction of the panels having mix ratio of 1:1:3 and 1:1:5 of (Portland cement: hydrated lime: sand). The test involves subjecting a square section of masonry, with global dimensions $400 \times 400 \times 105 \mathrm{~mm}^{3}$, to a compressive load applied along the diagonal. The experimental setup for the diagonal compression test is presented in Fig. 2.
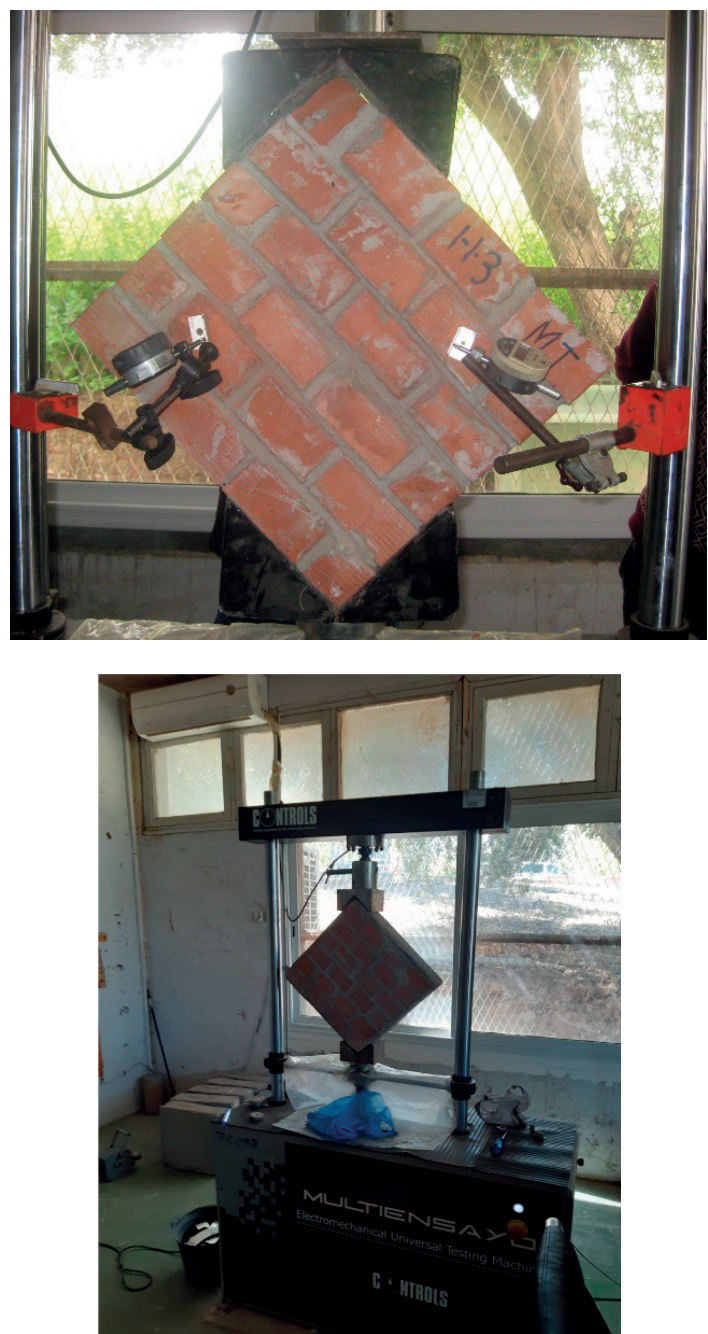

Fig. 2 Experimental setup of unreinforced masonry panels tested in diagonal compression 2. ábra Kísérleti összeállitás megerősitetlen falazat diagonális nyomószilárdság vizsgálatára

The walls are placed and centered diagonally between the two plates of the press with the help of the metal shoes. These allow the transmission of the load to the wall in the vertical direction. The load is applied using the hydraulic cylinder which is placed below the load cell. The measurement of displacements is carried out using two displacement sensors which are installed on the diagonal of the wall. All data, forces and displacements, are automatically recorded by a data acquisition system, and given automatically by the system. The loading is applied by a machine of capacity $500 \mathrm{kN}$. The loading speed is $5 \mathrm{~mm} / \mathrm{min}$. The tests were performed under displacement control in order to obtain the complete stressstrain curve of the panels. All tested wall panels were of similar dimensions in order to permit direct comparison of their failure loads (see Figs. 3, 4).
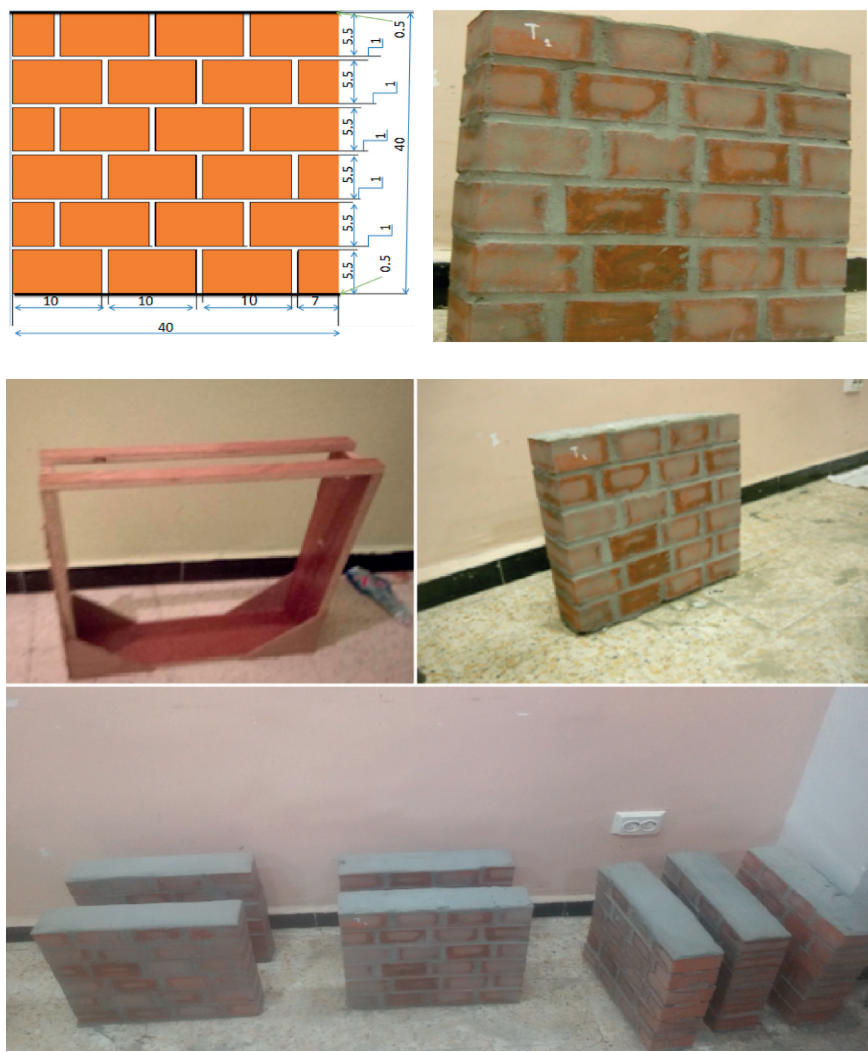

Fig. 3 Specimen preparations of unreinforced masonry panels

3. ábra Megerősités nélküli falazat minták előkészitése

The shear strength is calculated according to the state of stress in the center of the wall; isotropic or anisotropic. The calculation of the shear stress $\tau_{d t}$ is made according to ASTM 519 - 02[19]. considering a state of isotropic stress in the center of the wall.

$\tau_{d t}=\frac{\mathrm{P}_{\max }}{\sqrt{2 \times \mathrm{A}}}$

The lateral surface A is subjected to a maximum load $P_{\max }$ Area A is calculated with Equation (2) by considering w width, $\mathrm{h}$ height and $\mathrm{t}$ wall thickness.

$A=\frac{w+h}{2} \times t$

The displacement ductility factor $(\mu)$ is defined as the ratio between the ultimate displacement to the yield displacement:

$\delta_{\mathrm{u}}:$ displacement at ultimate load

$\delta_{\mathrm{y}}$ : displacement at the load causing yield condition

The shear modulus $\mathrm{G}$ is calculated in the zone of elastic stress with Equation (4)

$G=\frac{\Delta \tau_{e}}{\Delta \gamma_{e}}$

$\Delta \tau_{e}$ and $\Delta \gamma_{e}$ represent stress and elastic strain, respectively. 

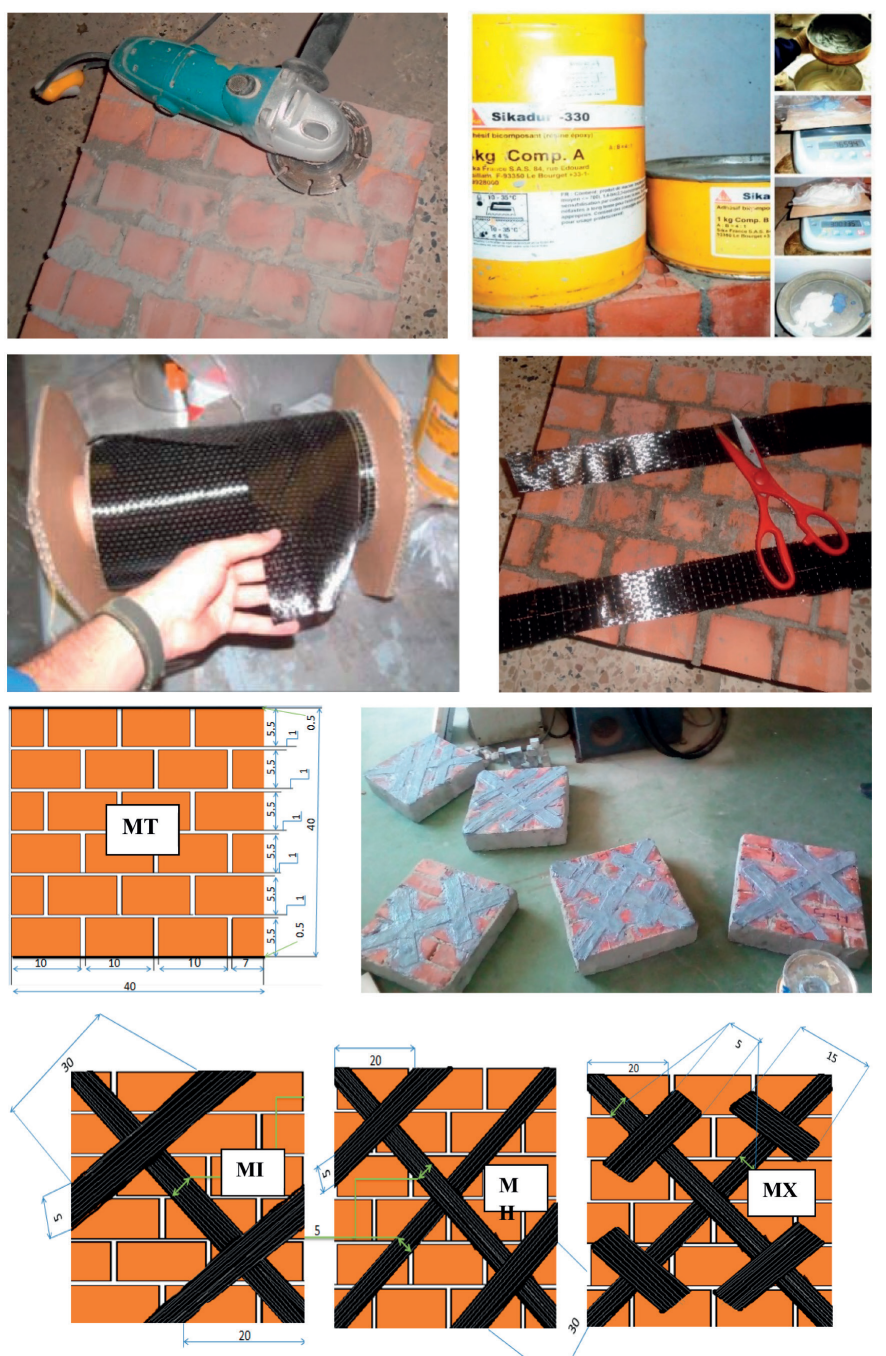

Fig. 4 Specimen preparations and configuration of reinforcing for masonry panels 4. ábra Megerősített falazat minták elökészitése

\section{Experimental results and discussion}

\subsection{Behavior of control walls}

In wall panels MTA and MTB cracking occurred predominately through the mortar joints in a diagonal, followed by a rapid decrease in load capacity. With load increasing, the wall exhibited a gradual increase in the width of predominately diagonally oriented crack, with further increase in load multiple cracks were observed in the panel before failure as shown in Fig. 5. The MTA control wall has a maximum shear strength of $0.5 \mathrm{MPa}$ corresponding to a maximum force of $33.66 \mathrm{kN}$. In addition, the MTB wall has a breaking force of $35.06 \mathrm{kN}$, which produces in this wall a maximum shear stress of 0.56 $\mathrm{MPa}$ (see Table 3). The shear stress-strain response of the tested unreinforced wall panels (MTA and MTB) is summarized in Fig. 7. For a comparison between the two responses, The wall panel constructed with mortar A failed at lower load compared to the wall panel type B,but with a slight difference. Both MTA and MTB wall panels exhibited an approximately linear shear stress-strain response until cracking, for the wall MTA followed by rapid degradation of shear strength once cracking propagated, but for wall MTB followed by a slight increase in shear strength and deformation capacity before the rupture.

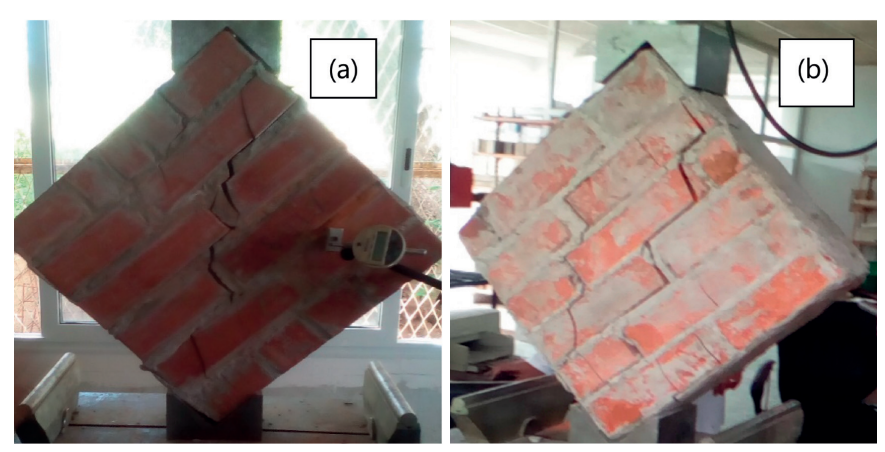

Fig. 5 Failure modes of control masonry panels: (a) MTA, (b) MTB 5. ábra A referencia falazat panelek tönkremeneteli módjai

\subsection{Reinforced masonry panels subjected to the diagonal compression}

In unreinforced walls, the tensile stress causes an appearance of cracks leading to a complete destruction. However, in the case of walls strengthened with CFRP composites, the tensile stresses are transferred to these strips and it results in a significant reduction of stress in the masonry wall. Regarding the overall response of the walls, the results obtained revealed a significant increase in shear stress from $65 \%$ to $270 \%$ compared to unreinforced walls. Likewise, it was found that the improvement in ductility for strengthened wall panels type A ranged from $74 \%$ to $80 \%$, whereas for wall panels type B it ranged between $80 \%$ to $88 \%$ (see Table 3). The CFRP reinforced panel failed suddenly due to a cracking along the compressed diagonal at the ends of the composite strips (see Fig. 6). The MRX and MRH walls have a maximum force of $55.27 \mathrm{kN}$ and $57.58 \mathrm{kN}$ respectively, which is a value of $1.82 \mathrm{MPa}$ and $1.85 \mathrm{MPa}$ for shear strength. and present better shear behavior with increase of $200 \%$. This reinforcement allowed to increase the ductility $\mu$ up to $88 \%$. Thus, when the joint of the mortar cracks, there is a redistribution of the force towards the part of the reinforcement which is in the vicinity of the crack. Therefore, the arrangement of the reinforcing composites has a very important effect on the local behavior of the structure, due to the stress distribution and the deformation of the structure. An application of CFRP composite on a $24 \%$ wall surface sufficient to increase wall ductility, and give almost the same results as that recorded when the fabric covers an area of 54 and $56 \%$. The first conclusion, which can be obtained from the experimental results, is that the wall panels reinforced by CFRP composite technique presented more ductile behavior compared with the control wall panels for each type of mortar (see Fig. 7). Moreover, the shear strength of reinforced wall panels is dependent on the mortar resistance.

\begin{tabular}{cccccccccc} 
panels & type & fiber & $\begin{array}{c}\mathrm{F}_{\max } \\
(\mathrm{kN})\end{array}$ & $\begin{array}{c}\tau \\
(\mathrm{MPa})\end{array}$ & $\begin{array}{c}\mathrm{G} \\
(\mathrm{MPa})\end{array}$ & $\gamma_{\mathrm{e}}$ & $\gamma_{\mathrm{u}}$ & $\mu$ & $\left(_{\mathrm{u}} \mu_{\mathrm{o}}\right)$ \\
$\mathrm{MT}$ & $\mathrm{A}$ & $0 \%$ & 33.66 & 0.50 & 77 & 0.023 & 0.027 & 1.16 & - \\
\hline & $\mathrm{B}$ & $0 \%$ & 35.063 & 0.56 & 78 & 0.029 & 0.031 & 0.94 & - \\
\hline MRH & $\mathrm{A}$ & $54.68 \%$ & 54.958 & 1.76 & 92 & 0.056 & 0.111 & 2.02 & 73.98 \\
\hline & $\mathrm{B}$ & $54.68 \%$ & 57.583 & 1.85 & 80 & 0.033 & 0.058 & 1.74 & 85.06 \\
\hline MRX & $\mathrm{A}$ & $54.06 \%$ & 50.815 & 1.61 & 117 & 0.027 & 0.057 & 2.1 & 80.87 \\
\hline & $\mathrm{B}$ & $54.06 \%$ & 55.274 & 1.82 & 128 & 0.028 & 0.049 & 1.78 & 88.83 \\
\hline MRI & $\mathrm{A}$ & $22.91 \%$ & 50.455 & 1.59 & 113 & 0.021 & 0.039 & 1.90 & 64.09 \\
\hline & $\mathrm{B}$ & $22.91 \%$ & 45.607 & 1.45 & 103 & 0.021 & 0.036 & 1.80 & 80.00 \\
\hline
\end{tabular}

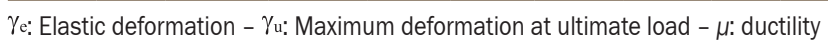
factor $-\left(\mu_{s} / \mu_{0}\right)$ : improvement between unreinforced and reinforced masonry walls fibers (\%): percentage occupation of the surface walls by carbon fiber band

Table 3 Ultimate shear strength and ductility factors for experimental tests of unreinforced and reinforced wall

3. táblázat A megerösitett és megerơsités nélküli falazatok nyírószilárdsága és duktilitási tényezöi 

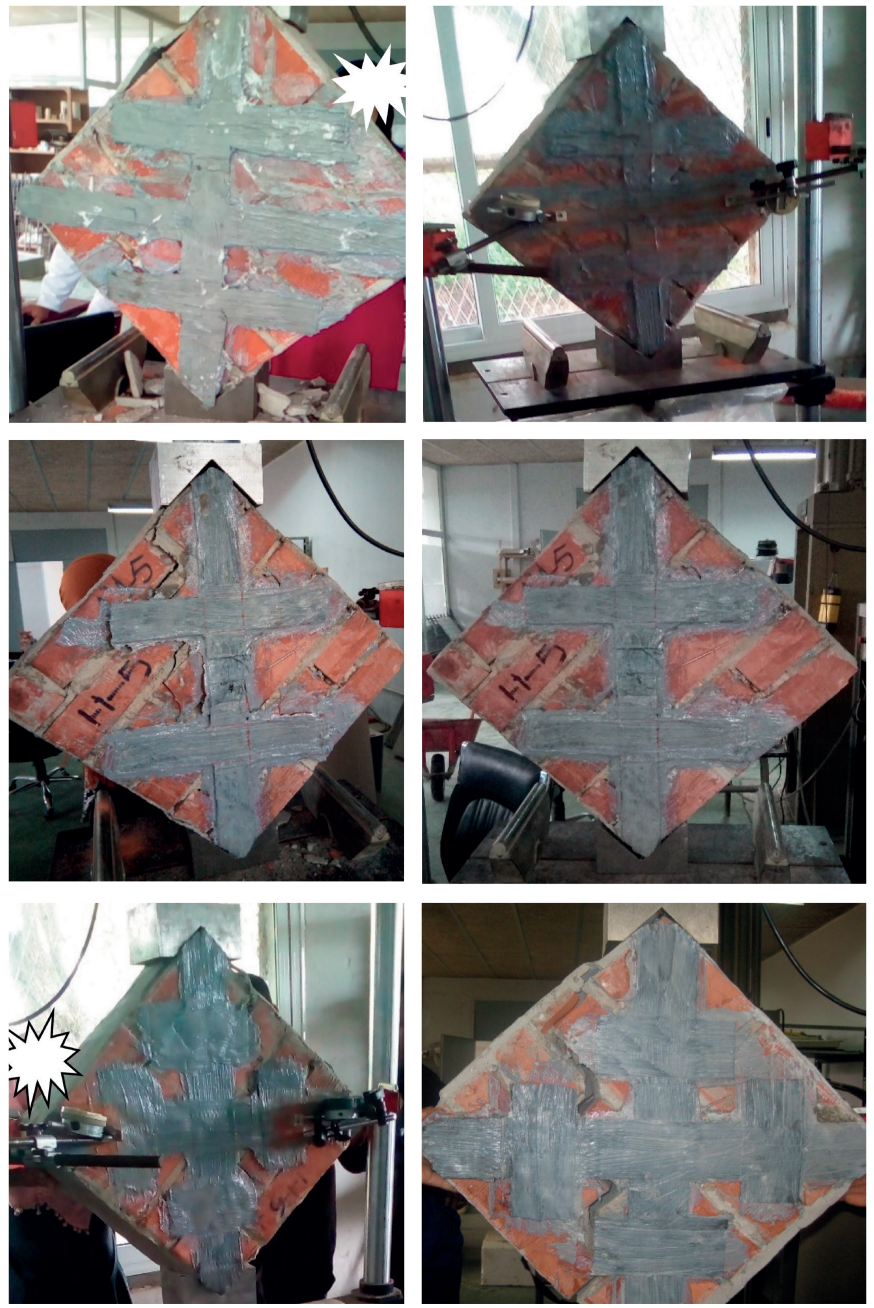

Fig. 6 Failure modes of all strengthened masonry panels: (a) MHA and MHB, (b) $M I A$ and $M I B$, (c) MXA and $M X B$

6. ábra Megerösitett falpanelek tönkremeneteli módjai: (a) MHA és MHB, (b) MIA és $M I B,(c)$ MXA és MXB

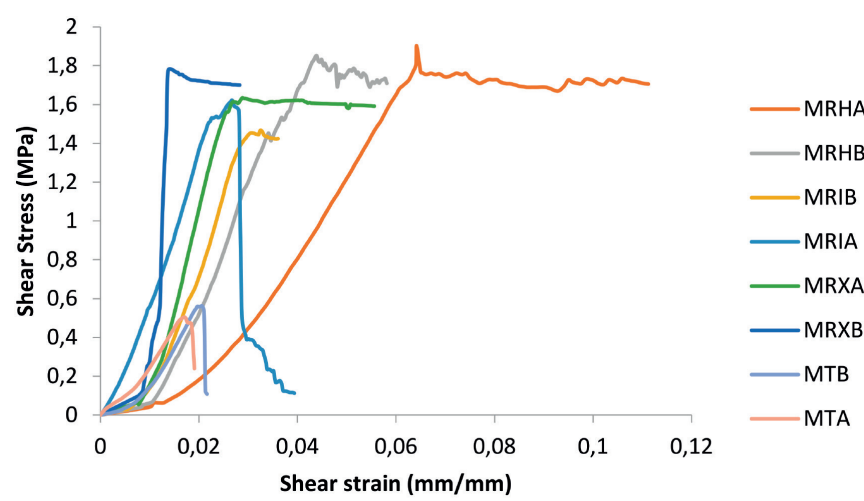

Fig. 7 Shear stress-strain relationship for unreinforced and reinforced masonry panels 7. ábra Nyirófeszültség-alakváltozás összefüggése megerösités nélküli és megerősitett falpanelek esetén

\section{FEM modeling for unreinforced masonry wall (MTB)}

\subsection{Material parameters}

In this study, the FE software, ABAQUS was used to evaluate the validity of proposed model (DMM) approach for predicting behavior of brick masonry wall. The units and mortar joints are modelled using eight noded 3D continuum elements with hour glass control and reduced integration (C3D8R), and the unit-mortar interface with zero thickness. The penalty friction formulation was introduced to model tangential behavior with a friction coefficient value of 0.6 . The normal behavior of the interface was modeled using "hard contact", the nonlinear behavior of brick and mortar was simulated by using the CDP model. The interface between unit and mortar was modeled through surface-to surface contact. The adopted modeling strategy used in this study is illustrated in Fig. 8.

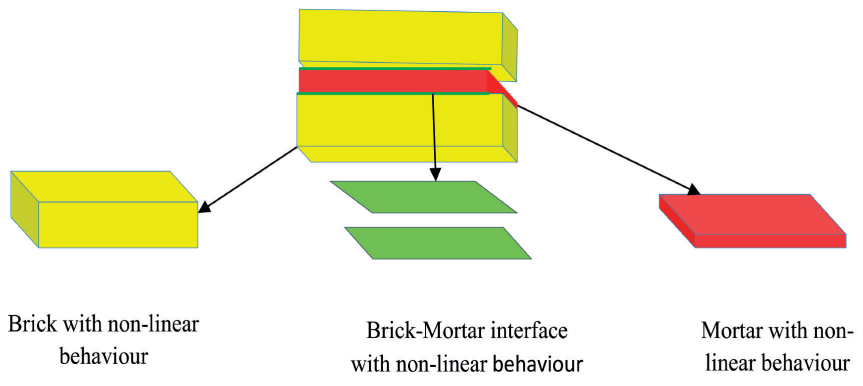

Fig. 8 Adopted detailed micro-modeling (DMM) approach

8. ábra Részletes mikro-modellezési megközelités

\subsection{Presentation of the numerical model}

To validate the model proposed in this study, the same wall that which was studied in the experimental part was chosen (MTB). Fig. 9 shows the geometry and loading condition for the FE model that has been implemented using ABAQUS.
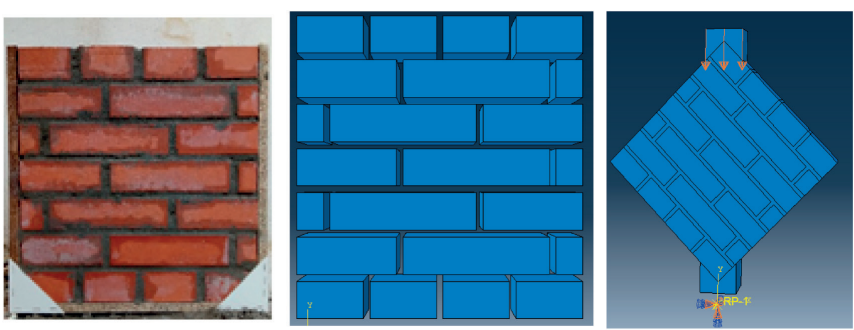

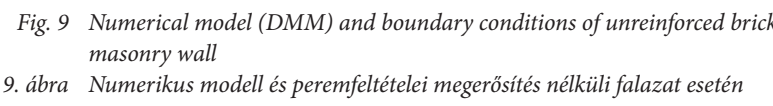

\subsection{Constitutive behavior of units and mortar \\ 4.3.1 Concrete damage plasticity (CDP) model}

The Concrete damage plasticity (CDP) model provides a general capability for modeling concrete and other quasibrittle materials. This model which was developed by Lubliner et al (1989) [20] and adopted by Abaqus is selected in this study to simulate the nonlinear behavior of the masonry units. This approach has been developed to predict the two main masonry failure mechanisms such as cracking under tension and crushing under compression. The CDP model uses the concepts of isotropic damaged elasticity in combination with isotropic tensile and compressive plasticity [21]. The level of damage is represented by damage parameters $d_{c}$ and $d_{t}$ as shown in Figs. 10 and 11. 

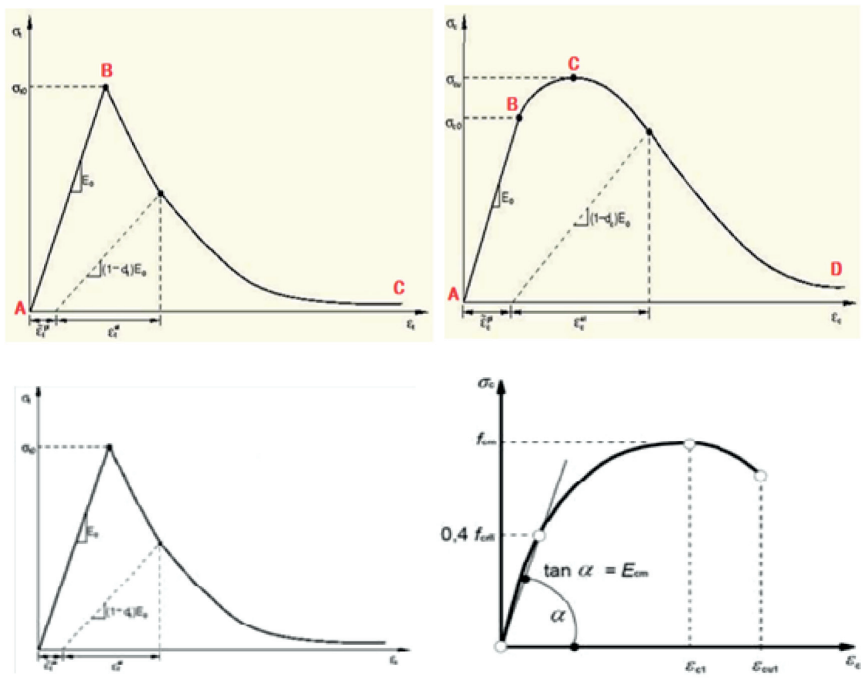

Fig. 10 Brick and mortar response to uni-axial loading; (a) Brick: in tension and compression; (b) Mortar: in tension and compression [19]

10. ábra Tégla és habarcs viselkedése egytengelyü terhelés hatására: (a) tégla: húzás és nyomás; (b) Habarcs: húzás és nyomás [19]

\subsubsection{Constitutive behavior of units-mortar interface}

In this model, brick-mortar interface is modeled by means of Coulomb friction criterion, in order to adequately reproduce the shear response of joint, the values of cohesion and friction angle for a Coulomb type friction model are provided by the envelop of the shear strength for different normal stress values, which was obtained experimentally by the triplet test (see Fig. 12). The interaction module of Abaqus/Explicit analysis was used to make the contact between units and mortar through the option surface-to surface contact. In this step it is necessary to define two contact properties: normal contact and tangential behavior.

\subsection{Model input parameter}

In this section, the input parameters used to reproduce the mechanical behavior of masonry wall using the detailed micromodeling approach is presented. The mechanical parameters for brick and mortar employed in this analysis were obtained from tests carried out in this research (see Tables 4, 5).

\begin{tabular}{lcc}
\multicolumn{1}{r}{ Elasticity parameters } & Brick & Mortar \\
Mass Density $\boldsymbol{\gamma}\left(\mathbf{k g} / \mathbf{m}^{\mathbf{3}}\right)$ & 2200 & 1800 \\
\hline Young's modulus $(\mathbf{M P a})$ & 10000 & 1880 \\
\hline Poisson ratio $\boldsymbol{v}$ & 0.2 & 0.18
\end{tabular}

Table 4 Mechanical properties of masonry unit and mortar 4. táblázat A habarcs és a falazat mechanikai tulajdonságai

\section{Plasticity parameters}

\begin{tabular}{lc} 
Dilation angle $\Psi\left({ }^{\circ}\right)$ & 20 \\
\hline Eccentricity parameter e & 0.1 \\
\hline Biaxial and unidirectional initial compressive strength ratio & 1.16 \\
\hline Stress ratio in tensile meridian $\mathbf{K}$ & 0.67 \\
\hline Viscosity Parameter & 0.0001
\end{tabular}

Table 5 Concrete damage plasticity of masonry brick and mortar 5. táblázat A falazat képlékenyedési paraméterei
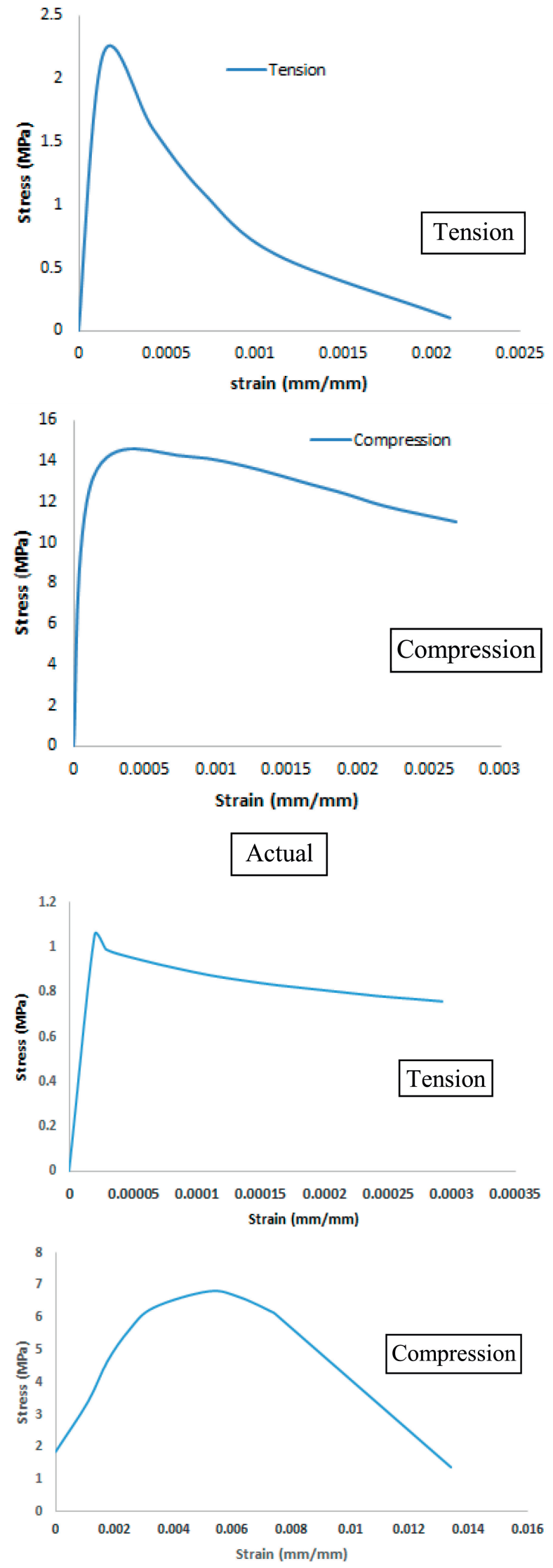

Fig. 11 Brick and mortar response to uni-axial loading; (a) Brick: in tension and compression; (b) Mortar: in tension and compression (present work)

11. ábra Tégla és habarcs viselkedése egytengelyü terhelés hatására: (a) tégla: húzás és nyomás; (b) Habarcs: húzás és nyomás (kísérletek alapján) 

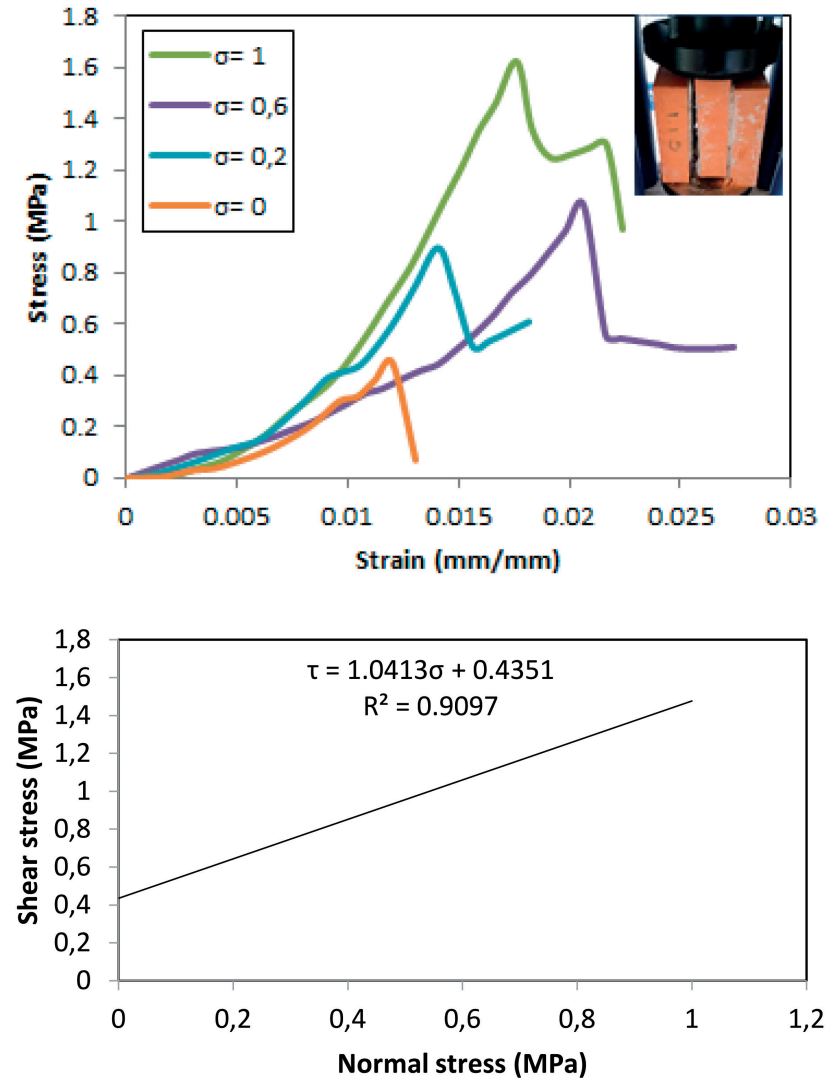

Fig. 12 (a) Stress-strain curves for various precompression, (b) Relationship between maximum shear stress and normal stress

12. ábra (a) Feszültség-alakváltozás görbék különböző elökompresszió esetén, (b) Maximális nyíró és normal feszültség összefüggése

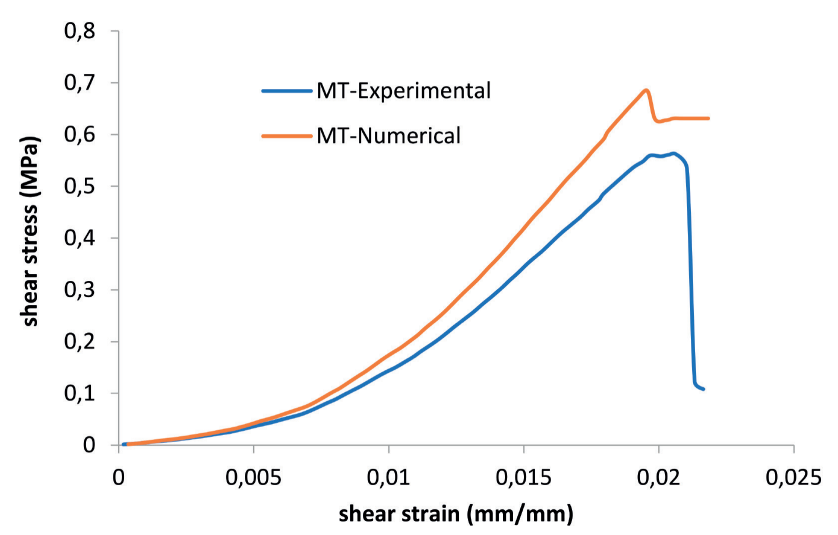

Fig. 13 Confrontation of curves $(\sigma-\varepsilon)$

13. ábra Görbék összehasonlítása $(\sigma-\varepsilon)$

The shear characteristics of the masonry and the brick/ mortar joint interaction parameters at the interface are determined on a masonry prism (triplet), the test results of 16 triplets for confining stress varying from 0 to $1 \mathrm{MPa}$ allowed us to determine the parameters shear strength and friction coefficient.

The shear strength (initial shear strength without any vertical stresses) is determined as follows:

$\tau=\frac{P_{\max }}{2 A}$

Where $\mathrm{P}$ is the shear load at failure and $\mathrm{A}$ is the cross-sectional area of contact between two bricks.
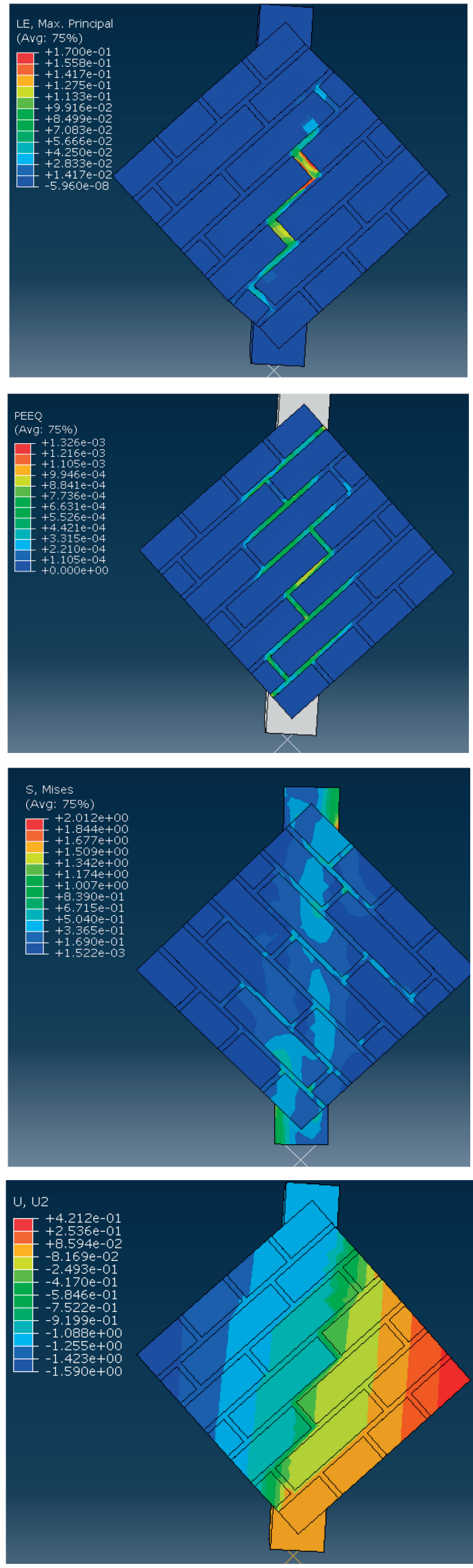

Fig. 14 Von Mises stress distributions, deplacement in the direction $y\left(U_{22}\right)$, plastic strain distributions (PEEQ) in the unreinforced brick masonry wall 14. ábra Von Mises feszültség eloszlás, y irányú elmozdulás $\left(U_{22}\right)$, képlékeny alakváltozás (PEEQ) megerösités nélküli tégla falazat esetén 


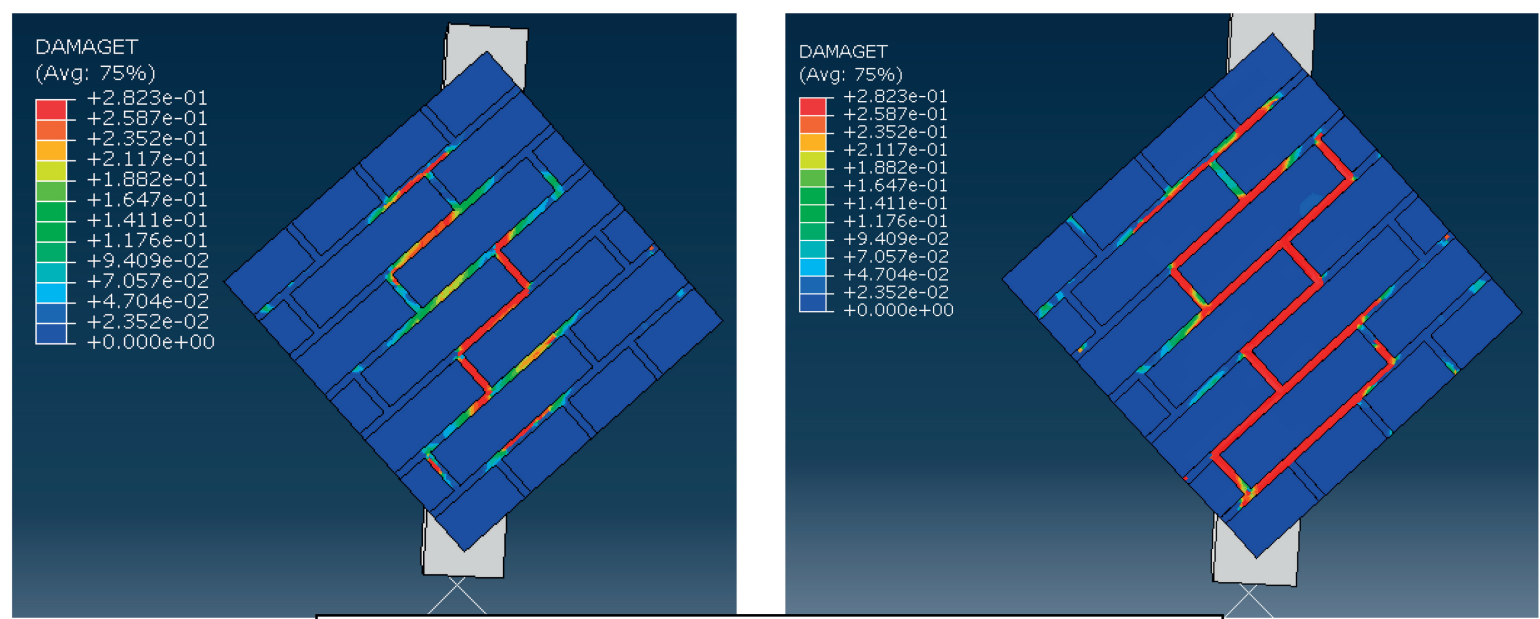

DAMAGET for Brick and Mortar at the initial of the step

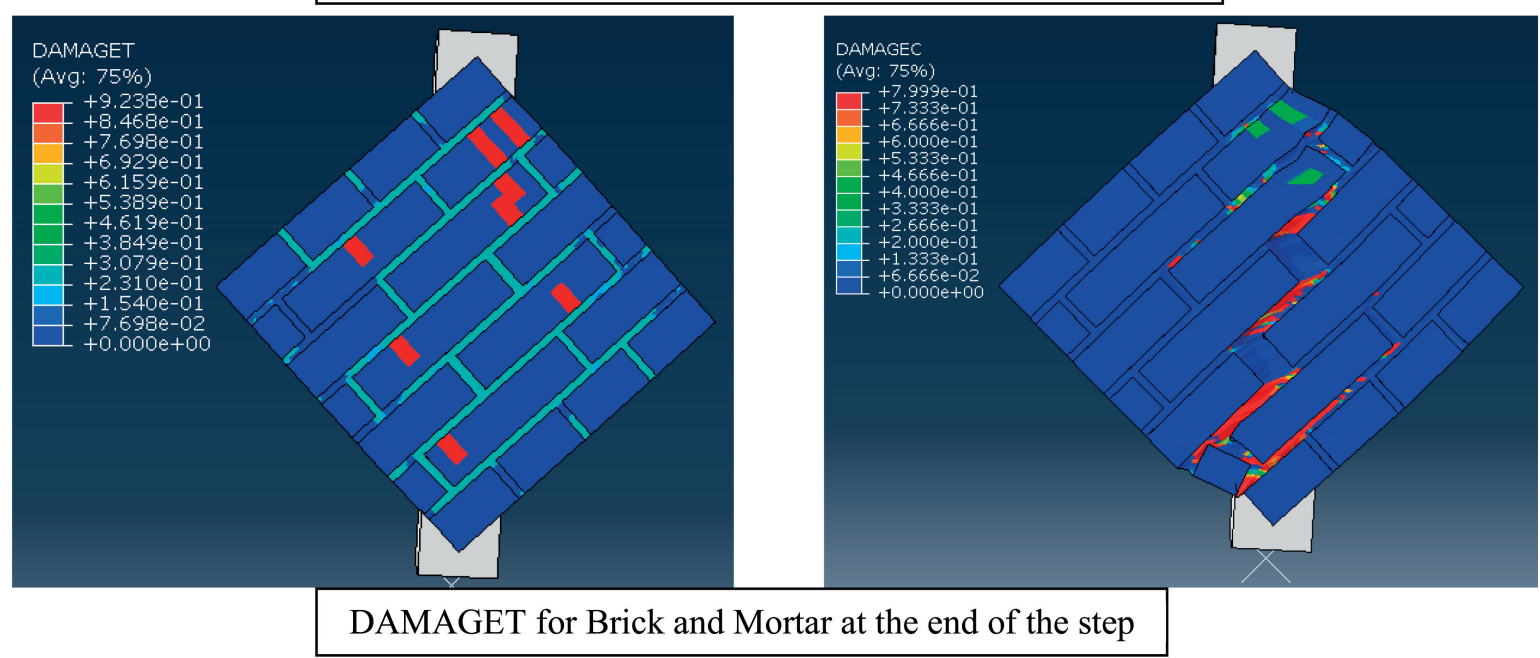

Fig. 15 Evolution of damage (DAMAGET, DAMAGEC) in the unreinforced brick masonry wall

15. ábra Tönkrementel kialakulása (DAMAGET, DAMAGEC) megerösités nélküli falazatokban

The shear strength of the unit-mortar interface $\tau$ of masonry under normal stress was characterized through Coulomb failure criterion $\tau_{u}=c+\mu * \sigma_{n}$

Where $\mu=\tan \varphi$ and $\mathrm{c}=\tau_{0}$ are the coefficient of friction and cohesion respectively.

The damage plasticity constitutive model was based on the following stress-strain relationship:

$\sigma=\left(1-d_{t}\right) \bar{\sigma}_{t}+\left(1-d_{c}\right) \bar{\sigma}_{c}$

where $d_{c}$ and $d_{t}$ were two scalar damage variables, ranging from 0 to 1 .

the damaged parameter $\left(d_{c}\right)$ is calculated by

$\mathrm{d}_{\mathrm{c}}=1-\frac{\sigma_{\mathrm{c}}}{\sigma^{\prime} \mathrm{c}}$

Where $\sigma^{\prime}{ }_{c}$ is the compressive strength of masonry.

Damaged parameter $\left(d_{t}\right)$ can be calculated by equation (9)

$\mathrm{d}_{\mathrm{t}}=1-\frac{\sigma_{\mathrm{t}}}{\sigma_{\mathrm{t}}}$

where $\sigma^{\prime}{ }_{t}$ is the masonry tensile strength

The uniaxial compressive and tensile responses of concrete with respect to the concrete damage plasticity model subjected to compression and tension load were given by:

$$
\begin{aligned}
& \sigma_{t}=\left(1-d_{t}\right) E_{0}\left(\varepsilon_{t}-\tilde{\varepsilon}_{t}^{p l}\right) \\
& \sigma_{c}=\left(1-d_{c}\right) E_{0}\left(\varepsilon_{c}-\tilde{\varepsilon}_{c}^{p l}\right)
\end{aligned}
$$

the effective uniaxial stress $\sigma_{t}$ and $\sigma_{c}$ were derived as follows:

$\bar{\sigma}_{t}=\frac{\sigma_{t}}{\left(1-d_{t}\right)} E_{0}\left(\varepsilon_{t}-\tilde{\varepsilon}_{t}^{p l}\right)$

$\bar{\sigma}_{c}=\frac{\sigma_{c}}{\left(1-d_{c}\right)} E_{0}\left(\varepsilon_{c}-\tilde{\varepsilon}_{c}^{p l}\right)$

\subsection{Comparison of results and discussion}

The response obtained from the model is illustrated by the stress-strain diagram and by the damage of the panel. Fig. 13 shows the numerical and experimental curves of the stressstrain relationship of unreinforced walls (MTB). The numerical results show a good agreement with the experimental results concerning not only at the initial rigidity of the elastic phase but also from the non-linear phase to the post peak response corresponding, but with a value from the numerical stress to the higher peak than the experimental value. Through these results show that the technique proposed in this study gives good results to analyzise the brick masonry wall behavior. 


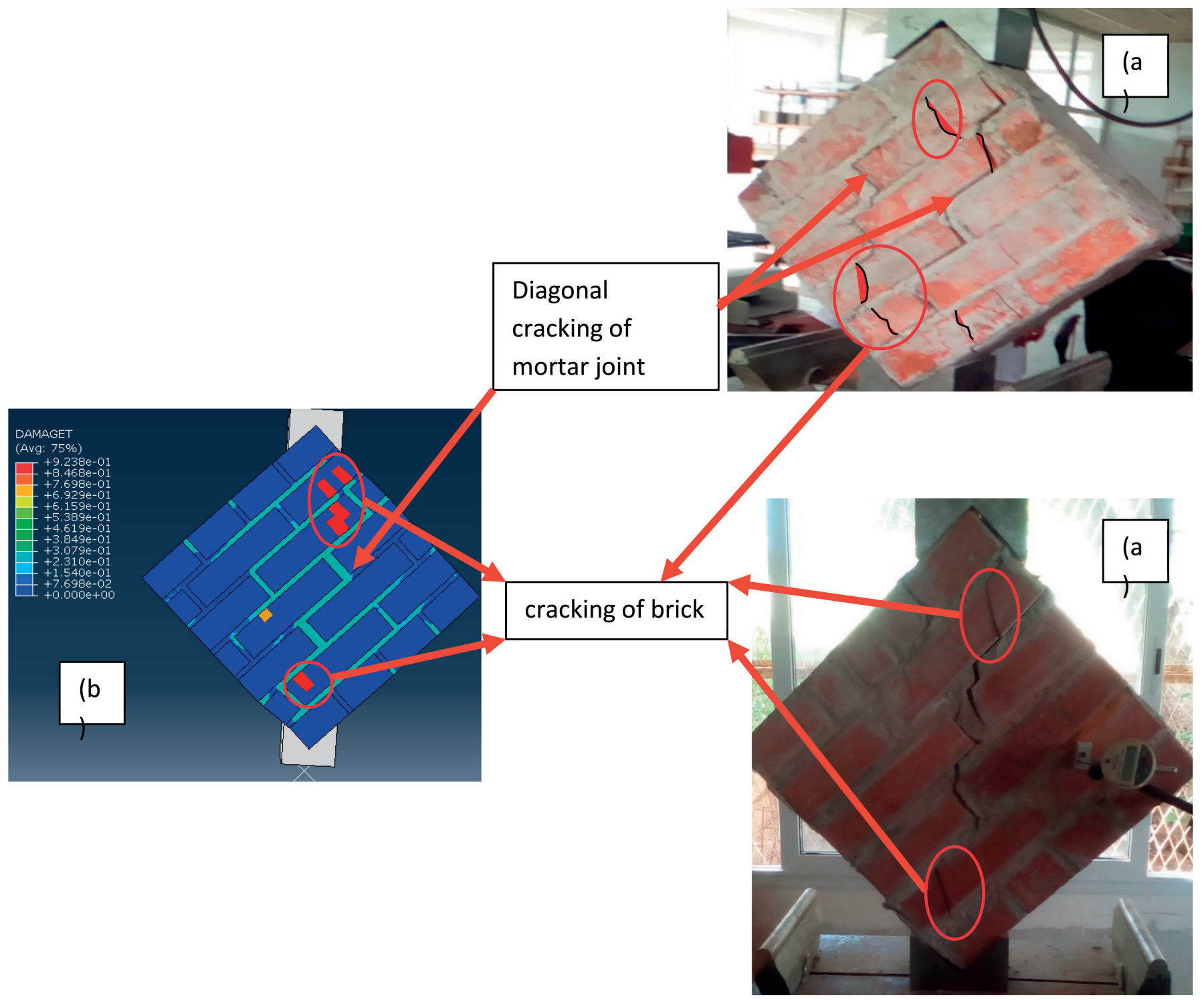

Fig. 16 Comparison between the numerical and experimental results concerning the crack pattern for the unreinforced wall MT: (a) experimental crack pattern; (b) numerical crack pattern

16. ábra Numerikus és kísérleti eredmények összehasonlitása a megerősités nélküli MT falazat törésképét kiemelve: (a) kísérleti eredmény; (b) numerikus eredmény

\subsubsection{Crack pattern and mode failure}

Figs. 14 and 15 show the initial cracking occuring along the bed and head mortar joints in a diagonal (initial step). As the vertical loads increase, more cracks occur in the mortar joints of wall from top to down. After that, cracks appear and propagate in the brick directly in final step. Same mode of rupture was found experimentally.

Fig. 16 shows a comparison of the crack pattern developed in the numerical and experimental test for the masonry wall MTB. The crack patterns observed in the mortar joint and brick during the experiment test and predicted by FE model resemble each other to a good extent. A good correlation was found not only at the crack pattern of mortar but also from the brick. However, the position of cracks at the brick in numerical case differs from experimental test, this can be explained by the numerical simplification which consists in considering that all the mortar joints have the same thickness, the same mechanical characteristics, which is not assured experimentally.

\section{Conclusions and future work}

There is significant potential for the application of FRP in the masonry industry, both in the construction and rehabilitation of older structures. In this paper, the behavior of brick masonry wall reinforced with externally bonded of CFRP composites is studied with experimental and numerical investigations. The obtained experimental results have been validated by a new modeling technique based on the DMM approach. The following conclusions were drawn from the experimental and numerical study:

- the increase in the proportion of sand in the mortar (from 3 to 5) led to an increase in the shear strength and the ductility of the masonry panels, especially in the case of reinforcement. 
- The improvement in shear strength for strengthened wall panels with CFRP composite ranged from 3 to 4 times (65\% to $270 \%)$.

- All reinforced wall panels showed a substantial increase in the ductility by $73 \%$ to $88 \%$ compared with unreinforced wall panels.

- The most significant increase in ductility was achieved by reinforcement in both sides of the wall panel by $\mathrm{X}$ shape with talents (MRX).

- The Finite Element model proposed in this paper shows considerable accuracy for the prediction of maximum shear load and failure mode.

- The developed model has been proved to capture the crack patterns and the stress distribution patterns in both of the brick and mortar.

- The CDP model is an appropriate hypothesis to represent the damage and the non-linear behaviour of brick and mortar.

- The behavior of the masonry is strongly governed by the behavior of the interface, Coulomb friction criterion are important to simulate the load transmission correctly between brick and mortar.

The good correlation between experimental and numerical curves encourages us to use this model in further works for the study of all type of unreinforced or reinforced masonry structure.

In addition, several factors such as type of loading and the characteristics of the single component brick and mortar should be considered in future researches in order to develop a suitable and optimal design approach for strengthening of in-plane loaded masonry walls. The numerical results for strengthened masonry wall will be discussed in future work.

\section{Acknowledgement}

The authors gratefully thank the CNERIB laboratory of Algeria for their availability to carry out this work.

\section{References}

[1] Martinné Dörömbözi Piroska (2007): Reinforcing and rehabilitation of stone structures, Építőanyag-Journal of Silicate Based and Composite Materials 59, 77-81. http://dx.doi.org/10.14382/epitoanyag-jsbcm.2007.12

[2] O. Csicsely Ágnes (2011): Short presentation of life cycle of earth construction, Építőanyag Journal of Silicate Based and Composite Materials 3-4, 42-47. http://dx.doi.org/10.14382/epitoanyag-jsbcm.2011.7

[3] Mahmood, H. and Ingham, J. M. (2011) Diagonal Compression Testing of FRP-Retrofitted Unreinforced Clay, Journal of Composites for Construction, 15(5):810-820. DOI: 10.1061/(ASCE)CC.1943-5614.0000209

[4] Valluzzi, M. R. - Tinazzi, D. - Modena, C. (2002) Shear behavior of masonry panels strengthened by FRP laminates, Construction and Building Materials, vol. 16, no. 7, pp. 409-416. https://doi.org/10.1016/S0950-0618(02)00043-0

[5] Haroun, M. - Mosallam, A. - Allam, K. (2001): Cyclic In-Plane Shear of Concrete Masonry Walls Strengthened by FRP Laminates. In Proceedings of Seventh International Symposium on Fiber Reinforced Polymers for Reinforced Concrete Structures, vol. SP-230-19, 327-339. ACI, Kansas City.

[6] Tumialan, G. - Morbin, A. - Nanni, A. - Medena, C. (2001): Shear Strength of Masonry Walls with FRP Composites. In COMPOSITES 2001 convention and Trade Show, Composites Fabricators Association, 6.

[7] Hamid, A. - El-Dakhakhani, W. - Hakam, Z. - ElGawady, M. (2005): Behavior of Composite Unreinforced Masonry-Fiber-Reinforced Polymer Wall Assemblages Under In-Plane Loading. Journal of Composites for Construction, 9(1), 73-83.

https://doi.org/10.1061/(ASCE)1090-0268(2005)9:1(73)

[8] Li, T. - Silva, P. - Belarbi, A. - Myers, J. (2001): Retrofit of Un-Reinforced Infill Masonry Walls with FRP.” In Proceedings CCC 2001 Composites in Construction, Porto, Portugal, October 10-12, 2001.

[9] ElGawady, M. A. - Lestuzzi, P. - Badoux, M., (2005): In-Plane Seismic Response of URM Walls Upgraded with FRP, Journal of Composites for Construction,vol. 9, no. 6, pp. 524-535.

https://doi.org/10.1061/(ASCE)1090-0268(2005)9:6(524)

[10] Dizhur, D. - Griffith, M. - J. Ingham, (2013): In-Plane Shear Improvement of Unreinforced Masonry Wall Panels Using NSM CFRP Strips, Journal of Composites for Construction, vol. 17, no. 6, https://doi.org/10.1061/(ASCE)CC.1943-5614.0000400

[11] Korany, Y. - Drysdale, R. ( 2006): Rehabilitation of Masonry Walls Using Unobtrusive FRP Techniques for Enhanced Out-of-Plane Seismic Resistance, Journal of Composites for Construction, vol. 10, no. 3, pp. 213222. https://doi.org/10.1061/(ASCE)1090-0268(2006)10:3(213)

[12] Lourenco, P. B. (1996): Computational Strategies for Masonry Structures, PhD thesis, Delft University of Technology, Delft, The Netherlands.

[13] Lourenço, P. B. (2008): Structural masonry analysis: recent developments and prospects.In: proceding of the $14^{\text {th }}$ International Brick and Block Masonry conference,Sydney, Australia

[14] D’Altri, A. M. - de Miranda S. - Castellazzi G. - Sarhosis V.(2018): A 3D detailed micro-model for the in-plane and out-of-plane numerical analysis of masonry panels. Computers \& Structures, 206. pp. 18-30. https://doi.org/10.1016/j.compstruc.2018.06.007

[15] Cristian Sandoval - Oriol Arnau (2017): Experimental characterization and detailed micro-modeling of multiperforated clay brick masonry structural response. Materials and Structures 50(34):1-17. https://doi.org/10.1617/s11527-016-0888-3

[16] EN 771-1, Specification for masonry units - Part 1: Clay masonry units. European Standard (2003).

[17] EN 1015-11, Methods of test for mortar for masonry. Determination of flexural and compressive strength of hardened mortar, European Standard (2007).

[18] RILEM. LUMB1(1994) Compressive strength of small walls and prisms. Technical Report, RILEM.

[19] ASTM (2002). ASTM E 519-02, Standard Test Method for Diagonal Tension (Shear) in Masonry Assemblages. ASTM International, West Conshohocken, PA

[20] Lubliner, J. - Oliver, J. - Oller, S. - Onate, E. (1989): A plastic-damage model for concrete. International Journal of Solids and Structures, 25;25(3):299-326. https://doi.org/10.1016/0020-7683(89)90050-4

[21] Dassault Systemes, Abaqus/CAE. USA (2014) Dassault Systemes Simulia Corp.

Ref.:

Hernoune, Houria - Benabed, Benchaa - Alshugaa, Madyan Abousnina, Rajab - Guettala, Abdelhamid: Strengthening of masonry walls with CFRP composite: experiments and numerical modeling

Építőanyag - Journal of Silicate Based and Composite Materials, Vol. 72, No. 1 (2020), 2-11.p. https://doi.org/10.14382/epitoanyag-jsbcm.2020.1 